\title{
THE JUVENILE COURT: CONTRADICTORY ORIENTATIONS IN PROCESSING OFFENDERS
}

\author{
H. WARREN DUNHaM*
}

Depending on one's historical perspective, the juvenile court has had either a short or long span of existence. Its history has been short when one attempts to survey the numerous tribunals which have been directed to the task of securing justice for men under some system of law. On the other hand, in the light of the earliest legal attempt to define the juvenile delinquent, it has had a relative long history, covering more than a fourth of this period. From the latter perspective, sufficient time has elapsed to justify a closer, more critical look at what the juvenile court is, what it does, and what it has accomplished.

In this analysis, there are five central objectives. First, the history of the juvenile court and the interacting social forces that have produced it will briefly be considered. Second, the image of the juvenile court that has developed from the implementation of reformistic ideals will be portrayed. Third, another image of the juvenile court, as derived from the traditional view of the law, will be constructed. Fourth, some of the consequences and problems that have resulted from the conflict of these two images will be discussed. And finally, some opportunities will be suggested for the juvenile court today. Such an analysis, it is felt, will illuminate not only what the juvenile court is, what it does, what it has accomplished, but perhaps where it is going.

\section{I}

Events and Forces Forming the Juvenile Court

The historical origin of the juvenile court is, no doubt, sufficiently familiar to the readers of this symposium to warrant but a brief recapitulation. While the first law defining juvenile delinquency was passed by the Illinois legislature in April $1899,{ }^{1}$ and the juvenile court itself began functioning in June of that year, its founding had been amply anticipated by certain legalistic precedents in equity and criminal law. More specifically, from the English courts of chancery or equity, the principle of parens patriae had evolved in the case of Eyre v. Shaftsbury in $1772 .^{2}$ This principle, which enabled the court to act in lieu of parents who were deemed unwilling or unable to perform their proper parental functions, paved the way for the juvenile

* Ph.B. 1929, A.M. 1935, Ph.D. r94I, University of Chicago. Professor of Sociology, Wayne State University. Research Director, State Psychiatric Clinic for Sexual Deviates, 1950; Fulbright Scholar, University of Amsterdam, The Netherlands, r956-r957. Author, Homeless MEN AND Their HanitatsA Research Planning Report (r953); co-author [with R. E. L. Faris], Mental. Disorders in Urban Aress (1939). Contributor to psychiatric and sociological journals.

${ }^{1}$ Ill. Laws 1899, p. 13I.

22 P. Wms. 103, 24 Eng. Rep. 659 (Ch. 1722). 
court to assume jurisdiction of dependent and neglected children. Even before this decision, however, the doctrine that the state under certain conditions had to act as a protector of minors had long been a part of the common law. ${ }^{3}$

But it is in dealing with delinquent children that the criminal law origins of the juvenile court are of significance. It had long been an accepted principle of the common law that a child under seven years of age could not commit a criminal act because he could not have mens rea, a guilty mind. ${ }^{4}$ From here, it was logical next to question the responsibility of children above seven years of age, and in so doing, the juvenile court law has been regarded merely as extending the application of a common-law principle.

Another development anticipating the juvenile court was the inauguration of probation as a device for dealing with offenders. This practice, initiated in Boston in $\mathrm{I} 84 \mathrm{I},{ }^{5}$ which included from the beginning adult as well as juvenile offenders, early highlighted some of the special protections that a child needed when brought before a court of law.

One other development which paved the way for the juvenile court was the establishment of special institutions for confining child offenders. The first institution for juvenile delinquents, the House of Refuge, in New York City, opened on January $I, I 825$, and by 1860 , sixteen of such institutions had been opened in the United States. ${ }^{\circ}$ These responded to the need long-felt by the reform element in American society that a child who had been convicted of violating a law should not be confined with hardened adult criminals in jails and penitentiaries, where, it was believed, only further demoralization and corruption could ensue. Even so, up to the first quarter of the twentieth century, children were still being punished by incarceration in institutions designed for adults.

Thus, it is seen that early legal precedents, the development of probation, and the establishment of special institutions for juvenile offenders anticipated the first juvenile court in Illinois, which was to become the prototype for legal tribunals dealing with children whose behavior or situation indicated positive state intervention. The concept of the juvenile court spread quickly and was favorably received throughout the country. Indeed, by 1923 , all states, with the exception of Connecticut and Wyoming, had enacted legislation defining a juvenile delinquent and establishing a special court for hearing children's cases; and by the early I940's, even the two hold-out states had come into compliance with this trend.

While these historical events define the establishment of the juvenile court, in a broader cultural sense, it can be regarded as the product of such social forces as our humanitarianism, on the one hand, and the growth of cities, on the other. The force of humanitarianism is well symbolized in the personalities of those women, Jane Addams and Julia Lathrop in Illinois, who agitated for the first

\footnotetext{
${ }^{3}$ See H. H. Lou, Juvenile Courts in the United States 3 (1927).

- See Rollin M. Perkins, Criminal Law 729-32 (I957).

- Sce Helen D. Pigeon, Probatton and Parole in Theory and Practice 85 (I942).

- See N. K. Teeters and J. O. Reinemann, The Challenge of Delinquency 429-47 (I950).
} 
juvenile court law. The high principles and unselfish motives which fired these women played a positive role in giving to the juvenile court, from its inception, the stamp of a social agency for dealing with a maladjusted child, rather than that of a punitive court attempting to exact retribution.

The rapid growth of cities, which characterized not only the United States, but the world in the nineteenth century, was also a significant factor. In 1800 , there was no city with a population of roo,000 in the United States, but by 1900, there were thirty-seven. ${ }^{7}$ This urbanization was a product of the factory system plus im. provements in agricultural technology. The cities grew not so much through natural increase, as through vast movements of people thereto from rural areas and from various European countries seeking jobs, opportunities, and a new life.

Most of these European migrants faced new and untested situations in the slum environments of our large cities. Their children, often caught in the conflict between European peasant values and the values reflected in American institutions, responded in delinquent ways and began to flood the jails, reformatories, and courts. Their parents, handicapped by language difficulties, were unable to comprehend or cope with these situations, and this tended to foster certain unforeseen functions of the emerging juvenile court, such as aiding the process of immigrant family adjustment, serving as an educational agency in American values, and often protecting the child from demoralizing home situations.

\section{A. Definitions}

Some difficulty has been experienced in determining exactly what the juvenile court is and what a juvenile delinquent is. The difficulty in defining the juvenile court stems from the fact that it is usually attached to a probate or county court and is generally of limited jurisdiction. Thus, while each state now has a juvenile court, its organization and the policies governing it vary markedly throughout the country. While most large cities have a court presided over by a special judge that is devoted exclusively to the processing of cases involving children, many rural counties merely have the probate judge change hats when hearing children's cases. In some jurisdictions, the juvenile court judge is appointed; in many other jurisdictions, he is an elected official. A few judges have looked upon the juvenile court judgeship as a career; others have seen it merely as a step in an upward political climb. Some judges take a human, personal interest in the children brought before them; others merely handle the cases within the framework of the law. Some juvenile courts, particularly those in large cities, have a staff of trained professionals, probation officers, social workers, psychologists, statisticians; others have hardly any. In some juvenile courts, the probation officers are trained social workers; in others, their professional training is minimal. In some juvenile courts, these professionals are under civil service and have tenure; in others, they are largely personal and political appointments. Some juvenile courts work closely with the numerous social

\footnotetext{
${ }^{7}$ See U.S. Dep't of State, Census Office, Second Census of the United States (180r); U.S.
} Dep'r of Commerce, Bureau of the Census, Stattstical Abstract of the United States (i957). 
agencies dealing with children; others have little or no contact with such agencies.

Three types of juvenile courts which have emerged in the various states have been identified. First, in most counties, other courts have jurisdiction over juvenile cases as well, and when hearing such cases they are referred to as juvenile courts. Second, there are some juvenile courts which are separate and divorced completely from other courts; these are usually found in counties with large cities. Finally, some juvenile courts are tied to special courts that handle selected social-problem cases, such as divorce and truancy, although there also has been a tendency to place such social-problem cases in juvenile courts which have an independent organization-a practice that has engendered certain support for a so-called family court.

A recent survey shows that in some forty states, jurisdiction is overlapping between the general criminal and juvenile courts. It is noted that the provision for alternate authority is related to the seriousness of the offense and/or the maturity of the child-defendant. The interpretive remarks on this matter are most relevant: ${ }^{8}$

Practice belies the motives which have supported the child welfare movement, revealing the limitations of our humanitarianism. More specifically, it points up the emphasis which our legal system continues to place upon incapacitation and deterrence-the protection of the public even at the expense of the child. In part, it may reflect too, the feeling that a fuller and more careful hearing should be given to serious cases than the juvenile court ordinarily provides.

When one turns to the definition of a juvenile delinquent, there is not so much variation as in the case of the juvenile court. All states have laws which, although varying in wording, show a common core of agreement in this regard. Thus, a child is uniformly considered delinquent if he acts in such a way as to violate a local ordinance or state law. In addition, most states further include such acts or conditions as "habitual truancy from school," "knowingly associating with thieves, vicious or immoral persons," "incorrigibility," "beyond control of parent or guardian," and "growing up in idleness and crime." These are only a few of the thirty-four items commonly found in the laws defining juvenile delinquency in the several states.

In general, state laws defining delinquency have moved from the specific to the generic. Accordingly, the legislation that established the juvenile court in Illinois defined a delinquent as "any child under the age of sixteen years who has violated any law of the state or any city or village ordinance." ${ }^{\text {"10 }}$ This concise statement contrasts markedly with the later New York legislation which defines a delinquent as: ${ }^{11}$

... a child over seven and under sixteen years of age (a) who violates any law of ... this state or any ordinance of the city of New York, or who commits any act which if committed by an adult would be an offense punishable otherwise than by death or life

${ }^{8}$ Tappan, Children and Youth in the Criminal Court, 261 ANNals 128, 132 (1947).

- See Frederick B. Sussasan, Law of Juvenile Delineuency: The Laws of the Forty-Eight STATES 20 (1950).

${ }^{10}$ IIl. Laws I 899, p. 137 .

${ }^{11}$ N.Y.C. Dom. ReL. Ct. Act $\$ 2(15)$. 
imprisonment; (b) who is incorrigible, ungovernable, or habitually disobedient and beyond the control of his parents, guardian, custodian or other lawful authority; (c) who is habitually truant; (d) who without just cause and without the consent of his parent, guardian or other custodian deserts his home or place of abode; (e) who engages in any occupation which is in violation of the law; (f) who begs or who solicits alms or money in public places; $(\mathrm{g})$ who associates with immoral or vicious persons; $(\mathrm{h})$ who frequents any place the maintenance of which is in violation of law; (i) who habitually uses obscene or profane language; or (j) who so deports himself as wilfully to injure or endanger the morals or health of himself or others.

Another observable trend has been the strengthening of the role of the juvenile court by assuring it wider jurisdiction over children's cases and by emphasizing that the child is not on trial for a specific crime. But some decisions contain language to the effect that the child's constitutional rights are to be assured through right of appeal-even though this right is seldom exercised in the juvenile court; ${ }^{12}$ and this matter has provided one of the principal foci for criticism of the juvenile court. Some judges and lawyers have maintained that the juvenile court in operation practically subverts the "due process" clause of the constitution in its zeal to apply the doctrine of parens patriae.

In addition to the generally diffuse manner in which they define delinquency, state laws differ markedly with respect to fixing the maximum legal age of a delinquent, varying from sixteen to twenty-one, with seventeen being the most common.

In summary, then, it should be noted that juvenile delinquency is a broad generic term which embraces many diverse forms of antisocial behavior of the child and which is defined somewhat differently in the various states, even though a converging tendency may be observed in the various laws.

It is only to be expected that these differences in court organization and in the definition of delinquency have made for wide variations in juvenile court policies and practices. Some juvenile courts are rigid, others are flexible; some are authoritarian, others are permissive; some are dictatorial, others are democratic. These contrasts are reflected in the number of cases heard unofficially in comparison with those heard officially, as well as in the use of various dispositions and the differences among juvenile court judges in the use of the dispositions available to them. But above all, they are reflected by the dominance of the image, as either a legal or social agency, that the juvenile court has of itself.

\section{II}

\section{The Social-Agency Image of the Court}

Juvenile courts in the United States run the gamut from the authoritarian legalistic tribunal at one extreme to the permissive, social-agency type of organization at the other. While there is no one juvenile court which coincides completely

\footnotetext{
${ }^{19}$ Herbert A. Bloch \& Frank T. Flynn, Delinquency: The Juvenile Offender in America
} Todar 353 (1956). 
with either of these idealized poles, it could probably be demonstrated that those which are an adjunct to another court correspond more closely to the legalistic image and those which have a completely independent organization, with a full-time judge, tend to adhere to the social-agency image. In this part, an attempt will be made to delineate the ideal social-agency image of the juvenile court. In so doing, those influences that were crucial in molding this image, the general character of this image, and some of its unanticipated consequences will be identified.

In the social-agency image, the purposes of the juvenile court are to understand the child, to diagnose his difficulty, to treat his condition, and to fit him back into the community. These purposes are held, to a greater or lesser degree, by the personnel that constitutes the juvenile court organization. More difficult, however, is the unraveling of all the tangible and intangible influences that have gone into constructing this social-agency image. In this connection, five influences have been selected which, in the judgment of the writer, have been primarily responsible for the evolution of this image and for its development at the expense of the juvenile court's more legalistic role. These are and have been: (I) the aggressive social-work orientation of the United States Children's Bureau; (2) the broadening jurisdiction of the juvenile court to include not only neglected and dependent children, but all matters of a legal nature involving children; (3) the gradual professionalization of social work; (4) various court decisions involving delinquency; and (5) the growing prospects of treatment through the increased acceptance by social workers of psychoanalysis, which has provided techniques for getting at the roots of conflict which supposedly produce delinquency. While each one of these influences has played its specific role, it would be quite difficult to assess their respective weights. It is sufficient merely to note that collectively they interacted and mutually reinforced an image of the juvenile court as a social-agency institution of independent status.

Thirteen years after the first juvenile court was established in Illinois, the Children's Bureau was created and lodged in the United States Department of Labor. ${ }^{13}$ The appointment of Julia Lathrop, an early proponent of the first juvenile court law, as its first head was a significant factor in enabling the emerging profession of social work to exercise a powerful influence over the development of the juvenile court. This influence has been reflected in the collection of statistics, the development of model juvenile court laws, the promulgation of standards for measuring juvenile court operation, the initiation of studies of juvenile court cases, the encouragement of juvenile courts to institute treatment services, the calling of national conferences of practicing professionals dealing with the problem, the emphasis on the need of probation officers with case-work training, and the attempts to construct educational and experience standards for those persons who would enter juvenile court work. All of these efforts and others have helped so to orient the juvenile court as to enable it to construct an image of itself as a social-work agency, designed primarily to meet the needs of the child. When Julia Lathrop left the

${ }^{18} 37$ STAT. 79 (IgI2), 42 U.S.C. $\$$ rgI (I952); 37 STAT. 737 (I9I3), 5 U.S.C. $\$ 616$ (I952). 
Bureau in I921, the high standards which she had set and the high ideals of child care and welfare for which she strived were carried forward by the distinguished social workers that followed her-Grace Abbott, x921-33, Katherine Lenroot, r934-51, and Martha Eliot, $1951-56$.

In short, the Children's Bureau, during its comparatively short history, has been most successful in shaping the image of the juvenile court as an agency for seeking the welfare of the child. Its failures, if they may be so termed, have been primarily of a negative nature-that is, it has failed to recognize that high ideals without sufficient knowledge are not enough, with the consequence that the social-agency image, which is at present the dominant image, has led to certain unanticipated consequences and unresolved dilemmas which have often placed the child in situations that are harmful rather than helpful to him. One commentator probably had these matters in mind when he noted that "the plight of the youngster has been increased by the deprivation of these [public hearings, trial by jury, right of appeal] and other ordinary elements of due process that are assured in the criminal court."14

The second influence, the broadening jurisdiction of the juvenile court, was a natural outgrowth of the reform spirit which dominated its founding. This helped, again, to emphasize the often-quoted characteristic of the juvenile court-that the child before it is not being tried for a crime, but rather that the court is acting in lieu of the parent and, as a benevolent one, by inquiring into the development and circumstances surrounding his maladjustment in order to determine the course of action that will best meet his needs and insure his continued welfare. This tendency of the juvenile court to deal with all cases involving children, however, has resulted in an obscuring and sloughing over of the differences between the delinquent and the dependent or neglected child and in a dealing with every child as if he were maladjusted or presented some kind of a problem. Social workers, in fact, in their conception of juvenile courts, unwittingly reflect this obscuring tendency: ${ }^{\mathbf{1 5}}$

The purpose of the juvenile court is not to inflict a penalty on a child but to save him from further delinquency and from neglect. Its success, therefore, depends upon a comprehensive understanding of all significant aspects of the case.

... If treatment is to be directed to causes and adapted to the needs of the individual, the child himself must be studied-his physical condition, his mental capacities, his personality and the driving forces of his conduct.

It seems only too clear. The purpose of the juvenile court is not to determine whether the child has committed any act for which he should be held; rather it is to get at the causes of his misbehavior in order that he can be given treatment appropriate to his needs.

The growth and establishment of social-work practice on a professional level has been a third influence that has helped to strengthen the social-agency image of the juvenile court. During the forty years following the birth of the juvenile court, the

14 Tappan, supra note 8 , at 130 .

${ }^{16} \mathrm{~K}$. F. Lentoot and E. O. LUndBerg, Juvenile Courts at Work-A Study of the Oroninization and Method of Ten Courts 88, 94 (U.S. Children's Bureau, Dep't of Labor Pub. No. 14I, 1925 ). 
growth of social work was rapid. In the colleges and universities, social work, often lodged in sociology departments, gradually broke away to form independent departments; in some universities, it emerged as a full-fledged, degree-granting graduate professional school. The professional organizations for social workers kept pace. The American Association of Social Workers, an outgrowth of the National Social Workers Exchange, was founded in I92I, the American Association of Medical Social Workers in 1918, the National Association of School of Social Workers in 1919, the American Association of Psychiatric Social Workers in 1926, the American Association of Group Workers in 1946, and the Social Work Research Group in r949. Within the last three years, all of these groups have joined to form the National Association of Social Workers. These professional organizations not only have helped to support the hands of those strategically-placed workers in the Children's Bureau, but also have served as pressure groups in various communities to bring about the appointment of the type of juvenile court personnel that would strengthen the social-agency image of the court.

The fourth influence here-certain court decisions-have also helped to move the juvenile court toward a social-agency image. The constitutionality of the legislation creating the juvenile court was quick to be tested. In one of the earliest of these cases, Commonwealth $v$. Fisher, the defendant attacked the juvenile court and its procedures, claiming that he had been deprived thereby of certain of his. constitutional rights. The court stated in part: ${ }^{16}$

The last reason to be noticed why the act should be declared unconstitutional is that it denies the appellant a trial by jury. Here again is the fallacy that he was tried by the court ... and no act of the legislature can deny this right to any citizen, young or old, minor or adult, if he is to be tried for a crime against the commonwealth. But there was no trial for any crime here, and the act is operative only when there is to be notrial. The very purpose of the act is to prevent a trial....

And so it went. Decision after decision helped to mold an image of the juvenile court that departed farther and farther from traditional legal principles. At the time, various criticisms were leveled at these decisions. One charge was. "socialism"; another, more reasoned, was that they were merely in keeping with a certain popular support that the new laws enjoyed. In any event, these decisions provided solid support for interpreting the laws to the end of converting the juvenile court into a kind of social agency.

Perhaps, the most outstanding influence impelling the juvenile court towards its social-agency self-image has been the early recognition that a child brought before the court must be treated for his problem, rather than be punished for his crime. This attitude supposedly opened the door for "scientific justice," where the child before the juvenile court would be studied in a total fashion-biological, psychological and sociological; a diagnostic judgment made; and a treatment prescribed which would meet unfulfilled needs, secure his protection, and insure his return

\footnotetext{
${ }^{16}$ Commonwealth v. Fisher, 213 Pa. 48, 53, 62 Atl. 198, 200 (1905).
} 
to social and psychological health. Thus, individualization of treatment was to be achieved in the juvenile court by the convergence of the enthusiastic support of reformers, the scientific advances in psychology and psychiatry, and the dominant individualistic theme of our culture.

With this initial treatment-orientation, the medical analogy was quick to appear in the literature, aided and abetted particularly by the development of psychoanalysis, with its varieties and the application of its insights into the delinquent child. ${ }^{17}$ From the study of neuroses and their emotional manifestations, it was, then, but a short jump to the viewing of delinquent behavior as a symptom of some underlying emotional conflict. ${ }^{18}$ When this occurred, it followed that each case must be studied carefully and completely to reach the source of the conflict in the child's personality that could account for the "acting-out"-even though socially-disapproved-behavior, and adequate provisions, psychiatric and/or case-work, made for its correction. As the doctor restores the physically-sick child to health, so it was urged, would the clinical team of psychiatrist, psychologist, and social worker restore the delinquent child to behavioral health, where those unpleasant "acting-out" symptoms would disappear.

As has been pointed out above, this treatment viewpoint has been present from the very beginning, despite the fact that no technique for treating delinquent behavior had been adequately formulated and tested. Even today, with the many advances of the basic sciences, such techniques are but imperfectly understood and do not, as many sophisticated therapists have recognized, meet expectations. ${ }^{10}$ In study after study, this fact has been demonstrated. The fact remains, however, that during the fifty-nine years since the founding of the juvenile court, the clamor concerning the need for treatment, nature of treatment, correct treatment procedure, and treatment facilities has continued to fill the pages of the professional journals, newspaper supplements, and professional lectures on delinquency to various community groups.

While treatment has been discussed here primarily in terms of the application of psychiatric and case-work techniques, the inference should not be drawn that these are the only activities regarded as treatment by the juvenile court. The fact of the matter is that under the impact of the treatment philosophy held by professionals, every action that the juvenile court takes is regarded as "treatment." Whether the juvenile court sends the child to the reformatory or the clinic, places him on probation or in a foster home, dismisses him with a lecture or without a lectureall is rationalized as treatment, especially by those professionals who have a deep

${ }^{17}$ See, e.g., A. AichHorn, Wayward Youth (1935).

${ }^{18}$ It should be emphasized that the claim is not advanced that delinquency is never the outgrowth of some emotional condition. It cannot, however, explain all delinquent behavior, as some of the uncritical adherents of the medical analogy seem to imply. The sole purpose here is to show the manner in which "treatment" philosophy has molded the social-agency image of the juvenile court.

${ }^{10}$ See Peck, Why Does a Young Delinquent Resist Treatment?. The Child, Nov. 1951, p. 35; Lippman, Treatment of Juvenile Delinquents, in National Conference of Social Work, Proceedings 317 (1945). 
need to view the juvenile court as an agency for treatment and never for punishment of the child.

The social-agency image of the juvenile court has had a dynamic quality-that is, it has been growing and expanding since the birth of the juvenile court in Illinoisand it is reflected in annual reports of various juvenile courts, in numerous publications of the Children's Bureau, in certain court decisions, and in many articles in professional and semiprofessional social-work journals. For example, here is a statement from an annual report of $1925:^{20}$

Or as the statute now reads, "The court from time to time may adjourn the hearing and inquire into the habits, surroundings, conditions and tendencies of the child so as to enable the court to render such order or judgment as shall best conserve the welfare of the child and carry out the objects of this act." As a result of this enactment the justices have been enabled to scrap once and for all the old legal trial of children with its absurd and obsolete limitations of testimony and to inquire into the causes of the children's neglect or delinquency untrammelled by narrow rules of evidence.

It is significant to note that the writer has no difficulty in considering delinquency and neglect together and is perfectly willing to throw out the "narrow rules of evidence" and the "absurd and obsolete limitations of testimony" in order to get at the "real causes" of the child's difficulty. It is difficult to refrain from observing, however, that it seems extremely relevant, if only in the interest of fair play, to establish the fact as to whether or not the child committed a particular act that would make him delinquent under the existing statute.

In this same report, the judge writes of the future of the court: ${ }^{21}$

We prefer to think of it as a definite arm of the government engaged in the task of protecting and correcting the handicapped children of the community and of supervising their social adjustments, but not extending its functions over matters which could be administered by other departments of state or even by semi-public agencies without invoking judicial action. . . Even now the court is seeking to treat every case, in which its assistance is invoked, to the end that the cause of the disease or disorder complained of may be removed and that its patients may be restored to perfect moral health. As time goes on its facilities for helping its patients and of achieving their social adjustments will be developed and improved. ... In short the court of tommorrow, as we picture it, will resemble in many respects the ideal which we are struggling, more or less imperfectly, to obtain today. It will administer the law faithfully and conscientiously but at the same time its emphasis will be laid more and more on the exercise of social justice by which alone the children who come before it may be readjusted, safeguarded and developed into future assets for the State.

This judge, only too clearly, has been willing to have his legal training modified or supplemented, as the case may be, by certain conceptions and values derived from a social-work point of view.

Perhaps, no clearer formulation of this social-agency image of the juvenile court

${ }^{20}$ Chizdren's Court of the City of New York, ANN. Rep. I6 (I925).

21 ld. at 3 I. 
is provided than a statement by the Wayne County Juvenile Court made over fifteen years ago: $:^{22}$

The average citizen thinks of the Juvenile Court in terms of a criminal court for young boys and girls, and believes that the Detention Home is a jail to which these boys and girls are sentenced.

These misconceptions overlook the great progress which society has made in the past one hundred years in dealing with delinquent children. For it is as recent as that, that children of tender years who violated the criminal laws were locked up in the same jails, were tried by the same prosecutors and judges, and in many cases received the same punishment, as hardened adult criminals. Often the punishment consisted of many years' imprisonment, and even, in a few instances, death. The protest by socially-minded people against this treatment by the criminal courts of juvenile offenders on the same basis as adult offenders, resulted in the Juvenile Court movement. Progressive people realized that the administration of social justice, at least so far as children are concerned, should not be based on theories of retribution and revenge, but rather on the principles of reformation and correction. They felt that children, by the very reason of their immature years, cannot and should not be held as strictly accountable for their acts as are adults.

The Juvenile Court is the outcome of this agitation for social justice for children. It is the first legal tribunal where the law works side by side with the sciences which deal with human behavior. The Court adopted the social case-work method, by which the child is treated individually in relation to his whole environment. It is in this procedure that the Juvenile Court differs from the criminal courts, where an accused person is sought to be convicted of and punished for having committed a particular crime. The juvenile delinquents who are brought before the Juvenile Court are not regarded as criminals, irrespective of the misconduct or offense with which they are charged. They are considered to be boys and girls who have become maladjusted and, perhaps through no fault of their own, have expressed their normal feelings and emotions in delinquent ways. The Court recognizes that these children need its special care, protection and understanding; and through proper supervision and guidance, it endeavors to divert the forces of delinquent behavior into normal and satisfactory channels.

This statement, which appears to be largely for public-relations purposes, epitomizes the spirit and aspirations of the juvenile court set in a social-agency framework. It goes almost without saying that there will be great disparity between actual practice and this pollyanna view of what the juvenile court aspires to be.

Within this social-agency framework, the juvenile court ideally should function in the following manner: A complaint would be made to the juvenile court's intake desk by the police, a social agency, a neighbor, a parent, or a socially-minded citizen. If the behavior difficulty could not be resolved with the complainant, process would issue and the child would be brought in. The child and its parents would be questioned by a social worker, and if the child could be released to its parents, this would be done; otherwise, the child would be held at a detention home pending a thorough social study of the case. In this latter event, the child himself would be variously viewed as maladjusted, having a problem, in trouble, or an example of need frustration or a type of "acting out" behavior. A social worker then would be assigned to the case to make the required social study.

${ }^{22}$ The Wayne County Juvenile Court i-2 (n.d.). 
Preliminary study of the case might indicate to the worker that the child's difficulty was not very deep-seated and that the case could be handled unofficially with a preliminary hearing and dismissed to the best interests of the child and others who were involved. On the other hand, preliminary inquiry might indicate the need for a complete social study; and, if so, the study would continue and might include thorough physical, psychiatric, and psychological examinations, as well as a thorough developmental picture of the child in his family and/or other social situation. The social investigation would logically lead to some diagnostic formulation involving the nature of the problem and the probable roots of the difficulty. On the basis of this formulation, some plan of treatment would be outlined which, of course, might include "institutional treatment." At this point, again, a decision would be made as to whether the case could be handled unofficially and recommended treatment carried out by the juvenile court clinic, child-guidance agency, a family agency, or a private psychiatrist, or whether the case should be handled officially and brought before the juvenile court judge, with the understanding that he would see that the recommended treatment was carried out. In either case, treatment would continue if the subject proved willing to accept it. If, however, he did not, more stringent measures would probably be recommended; in fact, the plan might include any one of the several dispositions, euphemistically called "treatments," that have been traditionally open to the juvenile court judge-namely, dismissal, supervised probation, foster-home placement, or institutional commitment. The juvenile court might also insist that the child be given psychiatric treatment by some independent agency. At this point, social-work supervisors, now termed probation officers, would take over and follow the child through the prescribed course. In the ideal social-agency-type juvenile court, however, the great majority of the cases would tend to be handled "unofficially."

As the juvenile court has moved in the direction of perfecting its social-agency image, several unforeseen consequences have emerged. For example, court decisions have helped mold this image as, one after another, they have affirmed that private hearings, the introduction of social-study material, the absence of a defense attorney, and the lack of trial by jury do not constitute a denial of due process because the child is not being tried for a crime. Accordingly, those legal safeguards which have been the cornerstone of Anglo-Saxon jurisprudence for centuries are not available to the child in the juvenile court because he is considered not to be responsible for his act up to a specified age, depending upon the state law, but rather is regarded as "having a problem." The disposition of the child in the juvenile court is, thus, almost entirely dependent upon the wisdom of the judge.

Another consequence of this emerging social-agency image of the juvenile court has been an attempt, particularly noticeable in the first six postwar years, to hold parents responsible for the delinquent acts of their child. The underlying reasoning is this: Social workers, via their varieties of psychoanalytic orientations, have regarded the home as the fundamental source of the love and security necessary to 
shape the child into a mature adult. When the child is not given this love and security, he experiences a feeling of frustration and unfulfilled needs, which leads to distorted and ambivalent reactions to one or both parents, and some resultant deepseated conflict or splintering of his ego. The parents, in turn, owing to their own inadequacies or because of the emotional state of the child, are able to provide nothing but the most erratic and inconsistent discipline and supervision. In such a family atmosphere, accordingly, the child may begin to "act out" his conflicts in delinquent ways. Now, this all-too-brief statement of the asserted psychological roots of delinquency in the family setting has been sold to certain juvenile court judges, with the result that schools for parents have been started, and parents have been summoned into juvenile court and, in some instances, given jail sentences because they have, from this perspective, been adjudged responsible for the delinquencies of their child. ${ }^{23}$

Another consequence of the juvenile court's assumption of the role of a socialwork agency is that the original differences among the conditions of dependency, neglect, and delinquency have gradually become obscure, and the juvenile court has approached each child as a young person who has a problem and needs help, regardless of his basic condition. It is but a step from this obfuscation to the general notion that the underlying cause of these diverse conditions is the same, despite the lack of evidence to support such a position.

A final consequence of this adherence to a social-agency orientation by the juvenile court-and perhaps the most telling one-is the moral confusion it occasions in both the child and his parents. In the popular mind, a court is an instrument for securing justice between persons and for securing the rights of the person charged with a specific criminal act by the state. When, however, the juvenile court fails directly to advert to the fact that a particular illegal act has been committed by the child and, in its zeal to "treat" the child, completely glosses over this matter, the final disposition of the child's case is very likely to seem to him confusing and even unjust. And his parents, in turn, will reflect this confusion, because on their social level, they cannot very easily accept the view that the child by virtue of his behavior is "sick" and needs "treatment," but rather are committed to the view that the court is there for justice and for punishing a person who has done something that is wrong.

One critic perceives this situation very clearly when he notes the lack of understanding of parents as to the function of a psychiatric clinic to which the juvenile court referred their children's cases. He points out that when cases brought before the juvenile court on charges of incorrigibility were referred to the clinic, the parents and the child considered the clinic action a part of the punishment for the offense instead of a means of treatment. ${ }^{24}$ Moreover, this attitude on the part of the child

${ }^{28}$ Space does not permit consideration of this problem in greater detail. The statutes have generally given judges authority to proceed against a parent or other adult where it can be shown that he has directly contributed to the delinquency of the child. See Teeters and Reinemann, op. cit. supra note 6 , at 200-06.

${ }^{24}$ O'Keefe, Mental Hygiene Facilities for the Juvenile Delinquent, Federal Probation, June 1948, pp. $31-35$. 
and his parents will continue to exist and plague the "treatment" process, because it will generally be impossible for the juvenile court to convey its "scientific" orientation to people whose morality is framed exclusively in terms of right and wrong.

It is also cogent to inquire how far we can carry certain theories of treatment of criminal behavior, on both juvenile and adult levels, without undermining the concept of legal responsibility; for it should be clear that a popular acceptance of the idea that no one is responsible for what he does would lead to chaos. Here, confusion is attributable to the deterministic character of science-the attempt to explain given behavior by isolating the interrelated factors antecedent to it-under which the doctrine of scientific responsibility replaces that of legal responsibility ${ }^{25}$ So, when the juvenile court attempts to help the child by "treating" his "disorder," it is literally using the child to collect data to substantiate certain theories of child behavior and to foist on him some inadequately-tested notions about treatment of juvenile misconduct, while, at the same time, chipping away at the concept of legal responsibility.

\section{III}

The Legal Image of the Court

It has been observed that the true social-agency image of the juvenile court tends to emerge only in those few highly-organized, independent juvenile courts to be found in large cities. The juvenile court as established by law in the great majority of states, however, is a part of a court of general jurisdiction and, as such, is part of a county court system. With such legal status, therefore, one can well appreciate the furious character of the conflict that has been occasioned by efforts to convert the juvenile court into a type of social agency, with traditional legal procedures deemphasized or eliminated and various treatments introduced in order "to cure" the child. The conflict has, in fact, been continuous, and in recent years, it has become even sharper as various studies have indicated both that many basic legal rights are being denied the child and his parents and that there may be a great gap between conception and execution of successful treatment of a "maladjusted" child. Thus, it has been observed that "measured by any reasonable standards the juvenile courts have failed to live up to the high expectations held by the early reformers."26

The conventional response to such observations has been that the juvenile court fails precisely because the community cannot or is unwilling to provide the necessary resources and facilities to do a first-rate job. Statements to the effect that there are not enough properly-trained probation officers, the judge is only part-time and has failed to grasp the juvenile court idea, detention facilities are inadequate, there are not sufficient treatment facilities in the juvenile court or community, there is a need for more psychiatric time, the people comprising the community must be educated to the function of the juvenile court, and the salary scale is inadequate are to

\footnotetext{
${ }^{25}$ See Green, The Concept of Responsibility, 33 J. Crmm. L. \& Crmmology 392-94 (I943).
}

20 Bloch and FlynN, op. cit. stupra note 12, at 3I7. 
be found scattered throughout the literature. While any one or all of these shortcomings may exist with respect to any particular juvenile court, however, there is no evidence convincingly to show that if these defects were remedied, juvenile courts in general would be able to do a better job in preventing recidivism in children who had once been found to be delinquent. In fact, much of the evidence appears to be exactly to the contrary. ${ }^{27}$ Even so, ameliorative measures might still be justified on the ground that the juvenile court would be able to perform its social-control function more adequately and more humanely.

What, then, are some of the central issues in this conflict between the socialagency and the legalistic orientations of the juvenile court?

First, the problem of the extent of jurisdiction of the juvenile court has been debated on two fronts: what relationship does it bear to other courts; and what type of cases should legitimately come before it? The problem of the relationship of the juvenile court to other courts was considered in the often-quoted case of People $v$. Lattimore. There, the Illinois Supreme Court reviewed and affirmed the criminal court conviction of the defendant while she was still a ward of the juvenile court, upholding the lower court's jurisdiction in these words: $:^{28}$

The Juvenile Court is a court of limited jurisdiction. The legislature is without authority to confer upon an inferior court the power to stay a court created by the constitution from proceeding with the trial of a cause jurisdiction of which is expressly granted to it by the constitution. . . . It was not intended by the legislature that the juvenile court should be made a haven of refuge where a delinquent child of the age recognized by law as capable of committing a crime should be immune from punishment of violating the criminal laws of the state, committed by such child subsequent to his or her being declared a delinquent child.

The problem is still widely-debated, however, and generally arises in one form or another when a child of juvenile-court age commits a capital offense. One solution has been to make the juvenile court independent by creating state-wide juvenile courts systems, as has been done in Connecticut, Rhode Island, and Utah. But it will take more time to determine where this system has improved the administration of juvenile justice. ${ }^{29}$

With respect to the types of cases that should come before it, there has been a tendency throughout its history for the juvenile court to assume jurisdiction over most cases involving children - often, it is asserted, more than it could satisfactorily handle. Thus, adoption, unmarried mothers, mother's pension, and sometimes divorce cases have been lodged in the juvenile court, as it has extended its aegis over cases of

${ }^{27}$ See W. Henly and A. Bronner, Treatment and What Happened Afterward (r939); E. Powers and H. Witmer, An Experiment in the Prevention of Juvenile Delinguency: The Camsbridge SOMERVILle YouTh STUdy (195I); Dunham and Knauer, The Juvenile Court and Its Relation to Adult Criminality, 32 Social Forces 290 (1954); Diana, Is Casework in Probation Necessary?, Focus, Jan. 1955; 'p. I; Adamson and Dunham, Clinical Treatment of Male Juvenile Delinquency: A Case Study in Effort and Result, 21 Am. Socro. REv. 312 (1956); R. W. England, What Is Responsible for Satisfactory Probation and Post Probation Outcome?, 47 J. CRIM. L., C. \& P.S. 667 (1957).

${ }^{28}$ People v. Lattimore, Ir9 N.E. 275, 362 Ill. 206 (1935).

${ }^{29}$ See Rubin, State Juvenile Court: A New Standard, Focus, July 1951, p. 103. 
dependency and neglect as well as delinquency. As noted above, this tends to confuse the juvenile court's function.

The practice of handling cases unofficially is another matter about which much controversy has raged over the years. This practice is extremely variable among juvenile courts, as certain juvenile courts handle no cases unofficially, while others may handle the bulk of their cases in this manner. The arguments advanced in support of the practice is that it is in keeping with the juvenile court's basic treatment philosophy; it keeps the child from having a court record; it enables professional opinion other than that of the judge to influence the case; and it saves the time and energy of the judge for the more serious cases. On the other hand, it is argued that the practice conduces inefficiency in that it diverts judicial attention to cases that should be handled by other agencies; it weakens the juvenile court's authority in the more serious cases; and it confuses any criteria which attempt to distinguish between court and noncourt cases and discourages other agencies from developing and devoting their resources to the prevention of delinquency. It almost goes without saying that the practice makes meaningless any attempt to report statistical comparisons between communities as to the frequency of delinquency.

Another problem confronting every juvenile court judge is that of balancing the welfare of the child, in accordance with the juvenile court's basic philosophy, against the protection of the community. This issue has not been articulated very clearly in the past, but recently it has received greater attention as it has been brought more sharply into focus. ${ }^{30}$ While it might be argued, in the spirit of Adam Smith's economic theory, that securing the welfare of the child will insure best the welfare of the community, this is not likely to have much appeal to those persons who have been injured in some fashion by the acts of a child. They may demand retribution and even revenge, which to them is justice. In fact, it is extremely doubtful that the aims of protecting and securing the welfare of the child can ever be completely realized until a sizable majority of the people in any community understands and accepts the basic philosophy of the juvenile court. This widespread lack of public rapport accounts for the perennial charge that the juvenile court is "coddling young criminals." Even if the necessary public understanding were brought about, however, the issue would still have to be faced as to how to deal most effectively with delinquent behavior in achieving both the welfare of the community and that of the child.

Another problem, as yet not adequately explored, concerns the limitations of individualized treatment within an authoritative court setting. While it has been accepted by many enlightened persons that punishment per se secures no beneficial results to the person or to the community, it is also becoming increasingly clear that our treatment techniques do not accomplish what we would like. In this area, however, our knowledge is quite deficient. We cannot well distinguish between

${ }^{80}$ See Standards for Speciajized Courts Dearing With Chitdren 2 (U.S. Children's Bureau, Dep't of Health, Education, and Welfare Pub. No. 346, 1954). 
those cases that might benefit from some form of psychotherapy and those cases that will not. Nor can we distinguish between those cases in which delinquency will, in any event, be arrested and those in which help is needed. Then, too, no matter what "treatment" disposition the court may use-probation, foster home-placement, referral to a treatment clinic, or commitment to an institution-the fact remains that it is likely to be viewed by the child and his parents as punishment and not treatment, although these devices probably afford a more individualized and progressive scheme of punishment than various kinds of treatment per se. There is, finally, some doubt as to the validity of one assumption of treatment philosophy seldom mentioned in the literature-the assumption that the child facing the therapist is either not thinking or, if he is, he is freely entering into cooperation with the therapist to achieve a cure. With delinquents, nothing could be farther from reality. For quite often, the delinquent "patient" is not only thinking, but thinking of how he can beat this "rap"; and in trying to do so, he will not hesitate to attempt to manipulate the therapist, who will have to be steeped in a knowledge of the delinquent's world if he is not to be duped.

These issues must all be resolved if the juvenile court is to fulfill a valid legal function. $^{31}$ Ideally, the juvenile court would be independent of other courts, with its jurisdiction carefully defined by law. The law would, for the guidance of the juvenile court, carefully and precisely define the specific acts for which a child could be held as a delinquent. At the intake desk, a complaint would be registered with the appropriate evidence to support the contention that an act of delinquency had been committed. The gathering of such evidence would be primarily a police task, in which assistance might perhaps be rendered by a probation officer of the juvenile court. The probation officer, the police, and the juvenile court referee would decide whether or not the evidence was sufficient to warrant a delinquency petition. If not, the child would be dismissed with a warm, friendly attitude; if the evidence was sufficient, however, the child would be held either in the custody of his parents or guardian or in a detention home for a juvenile court appearance.

When brought before the juvenile court, after a very short detention period, the first task of the judge would be to inform the child and his parents of all their legal rights according to law, particularly their right to legal counsel and appeal. The judge would then hear the evidence and find whether or not the child had committed a delinquent act. The judge, before determining the disposition of the case, would then confer with those professional members of his staff who had worked on the case to determine if some consensus had been reached among them as to which available disposition would serve best to secure both the welfare of the child and protection for the community. He would then pronounce the disposition that had been decided in consultation. Such dispositions even though mild and humane, would bear a punishment and not a treatment label. The atmosphere

\footnotetext{
${ }^{81}$ In constructing this legal image, the focus here is primarily on delinquency cases and excludes other
} kinds of cases handled by juvenile courts. 
of the juvenile court at all times would be formal, dignified, and authoritative. The judge, as representative of community authority, would always attempt to impress the child and his parents with the gravity of the situation and the consequences that would likely ensue if such act or acts were repeated. Such a juvenile court would have no facility for clinical treatment of the child, for it would be recognized that treatment can be carried on only when a case is not being adjudicated. Nor would it indulge in the unofficial handling of cases. For it should be clear that if no delinquent act has been committed, the taking of any action with reference to the child is a violation of his rights, unless the child and/or his parents request help -and in that event, he and/or they would be referred to the most appropriate available agency.

\section{IV}

\section{Conflict of Images-A New Opportunity}

The proponents of these two images-the social-agency and the legalistic-which have here been delineated have been engaged in ideological battle over the juvenile court during its sixty years of existence. To be sure, the social-agency image has been the more dominant and aggressive, although in recent years, the balance has swung back somewhat toward the legalistic image. ${ }^{32}$ The conflict of these images, however, still clearly appears in juvenile court attitudes and the decisions of the various judges as they seek to cope with the cases before them. A slight ironical twist may be seen when an eminent judge describes the juvenile court as comparable to a hospital or clinic where the "sick" patient is diagnosed, hospitalized, treated, and discharged, ${ }^{33}$ while a well-known social worker states that the juvenile court is first a court where legal responsibility is established specifically by law with respect to certain behavior and conditions of children and adults. ${ }^{34}$

The clash of these two images in the history of the juvenile court has been of crucial significance, because it tends to force a re-examination of all theories concerning the etiology of delinquent behavior, as well as theories concerning the most effective ways of handling delinquents to produce the desired results. It has brought the juvenile court to what one critic, drawing an analogy from the field of mechanics, has termed "dead center," where no force can move it either way and it slowly

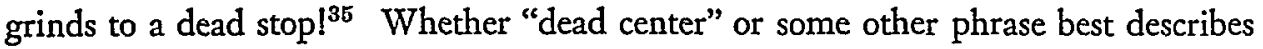
the present situation of the juvenile court, however, is beside the point; the fact still remains that the juvenile court has not demonstrated the accomplishments which

${ }^{32}$ See, e.g., Paul W. Tappan, Comparattve Survey on Juvenile Delinquency (1952); Killian, The Juvenile Court as an Institution, 26r Ansals 89 (1949). Over thirty years ago, Eliot saw the need to separate judicial and treatment functions. See Eliot, The Project Problem Method Applied in Indeterminate Sentence, Probation, and Other Re-educational Treatment, in THE CHILD, THE CIINIC AND THE CouRt 102 (1925):

${ }^{33} \mathrm{P}$. W. Alexander, of Juvenile Court Justice and Judges, in NPPA YeArbook 187, 192 (1947).

${ }^{34}$ Alice Scott Nutr, The Juvenile Court and the Public Welfare Agency in the Child Welfare Program (U.S. Children's Bureau, Dep't of Health, Education, and Welfare Pub. No. 327, I949).

${ }^{35} \mathrm{McCrea}$, Juvenile Courts and Juvenile Probation, 3 N.P.P.A.J. 385 (1957). 
would justify the faith of its founders. But the present situation of the juvenile court might well afford a unique opportunity-that is, the opportunity to sponsor and encourage scientific research inquiries to answer some of the pressing questions that this clash of images has produced. Both the spirit and tradition of the juvenile court make it possible to do this.

Lack of space limits a detailed discussion here, and so only a few problems suitable for research can be suggested. There is a great need to determine how the juvenile court can be made most effective, both as an instrument of social control in the community and as an instrument for arresting delinquent behavior in youth. Let us consider this experiment: We hear from many sources that a delinquent child needs psychological treatment and not punishment. Therefore, let us set up a wellequipped clinic, with the best-qualified personnel that it is possible to obtain, even at the expense of paying them salaries somewhat higher than the prevailing scales in the community. When such a clinic is established, from the signed complaints coming to the juvenile court, one child would go to the clinic for appropriate treatment and one would go to the juvenile court, which would function exclusively as a legal tribunal, using the dispositions available to it. The clinic would only take enough cases to insure an adequately-sized sample, previously agreed upon. Two to three years after treatment, a follow-up study would be made on both juvenile court and clinic cases, primarily to determine if the subjects still continued their delinquent behavior or were in any way dependent problems for the community. The writer strongly suspects that there would be no significant differences in outcome between the juvenile court and clinic cases because of the almost universallyoverlooked fact that clinic treatment may be useful in only certain types of cases. If the clinic succeeded with certain kinds of cases, they might be hidden in the figures and would be balanced by those cases in which a favorable adjustment would have been effected regardless of the disposition made. This suggests that successfully treated cases are those that would recover if nothing were done.

There is need also to determine the relative merits of the different disposals available to the juvenile court and the kind of cases that might respond most appropriately to each. Similarly, there is need to determine, if possible, the significance of the impact of the court experience upon the child: Will it be more crucial to certain children coming from some segments of society than to other children from other segments? In evaluating each study, a two-faceted standard would be employed: does the child continue his antisocial behavior as an adult; and/or does the child continue to have a socially-unacceptable dependent status as an adult?

These research suggestions are only a few of the tacks that the juvenile court might pursue to help ease itself from its present static position. Research might also promote the divestiture of the built-in egocentric protective mechanisms that are found in certain juvenile courts and direct attention once again to the problem of the child and the task of transforming the juvenile court into an effective agency for the social control of youth. 
There would hardly seem to be any dispute among professionals in the criminological field that a philosophy of treatment and reformation is of a morally higher order than is a philosophy of punishment; there is less certainty, however, about the views of the general public on this matter. But regardless of public attitudes, the question of how far and under what circumstances the reward-penalty system of a society can be modified is most crucial. For it would seem that in any kind of social structure, there will always be certain persons who cannot and will not be accommodated. Some of these persons will be so-called criminals, and the central sociological task is to discover, if possible, what their minimum number should be and then to determine the best social arrangements to keep their number at this level. With respect to juvenile delinquents, this probably represents the "hard core" which fails to respond to any therapeutic approach.

The juvenile court, most markedly of all our agencies for handling sociallyaberrant individuals, has adhered to the philosophy of treatment and reformation, with the lofty ideal of safeguarding, almost at any cost, the welfare of the child. While this ideal is eminently praiseworthy and expressive of the humanitarian quality of American culture, the question can, however, and should be raised as to whether the existing social-agency-type juvenile court has succeeded in creating the most appropriate conditions for arresting a child's misconduct and for providing him with those personality strengths that will enable him to adjust to the community in a socially acceptable manner. This is a question, it is submitted, that merits the most careful and thoughtful examination.

In this paper an attempt has been made to portray two idealized conceptions of the juvenile court-the social-agency and the legalistic-the nature of the conflict between them, and the resultant state of rigidity into which it has become frozen. While the social-agency image has been the most dominant and aggressive, the legalistic image still remains with us in many juvenile courts, hidden in the traditions of the criminal law. The future of the juvenile court hinges upon our capacity to analyze carefully the issues in this conflict in order that we may devise the type of institutional procedure-in conformity with our existing knowledge-that will best insure both protection for the community and essential personality strengths for our youth. 